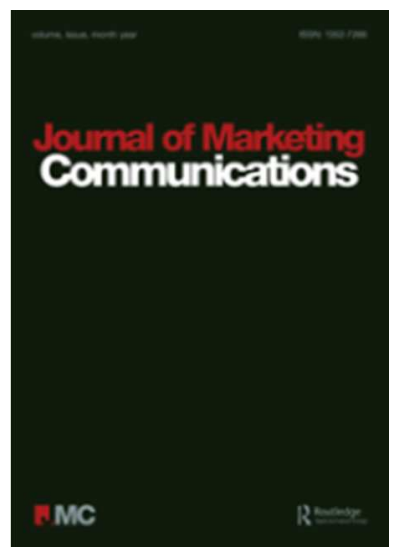

Political Brand Identity. An examination of the complexities of Conservative brand and internal market engagement during the 2010 UK General Election campaign

\begin{tabular}{|r|l|}
\hline Journal: & Journal of Marketing Communications \\
\hline Manuscript ID: & RJMC-2013-0038.R2 \\
\hline Manuscript Type: & Original Papers \\
\hline Keywords: & $\begin{array}{l}\text { political communications, internal market, political branding, Conservative } \\
\text { party }\end{array}$ \\
\hline \multicolumn{2}{|l}{} \\
\hline
\end{tabular}

SCHOLARONE ${ }^{\text {M }}$

Manuscripts

URL: http://mc.manuscriptcentral.com/rjmc Email: p.j.Kitchen@hull.ac.uk 
This paper seeks to build an understanding of the importance of internal communications when building a strong political brand. Using the Kapferer's brand prism as a conceptual framework, the paper explores UK Conservative party members attitudes towards the development of the Conservative brand as personified by David Cameron. There are clear implications for political strategists as the findings suggest that it is crucial to engage the internal market in the co-creation of the marketing communications strategy for, as brand evangelists they interpret the brand promise at the local level. 


\section{Political Brand Identity. An examination of the complexities of Conservative brand and internal market engagement during the 2010 UK General Election campaign}

\section{Introduction}

As the most successful UK political party in the twentieth century (Norton, 1996; Denham and O’Hara, 2007; Lloyd, 2006), the Conservative party experienced a hiatus going into the new millennium. New Labour was elected in 1997 and successfully defended their majority against a Conservative Party led by William Hague, Iain Duncan-Smith and Michael Howard respectively. Each Conservative Party leader provided a different perspective on the image, policy and presentation of the Conservative brand reflected through their own Conservative value system. In politics, the consistency of the political party product offering is crucial to electoral success (Dean and Croft, 2001), and this was exemplified in the 'New Labour' brand and its 'on message' approach to political communication in 1997 (Gould, 1998). Brands are powerful heuristic devices that encapsulate key values of the product or service and there is an emerging body of literature that examines the concept of branding in a political context (Lilleker and Negrine, 2003; Reeves et al., 2006; Scammell, 2007; Smith, 2001; 2009; White and de Chernatony, 2002). Nascent research has focused on branding the party, leader, and political campaigning, whilst Smith and French (2009) examined political branding from a consumer perspective. However, there has been little discussion on the internal market and the political brand. The internal market plays a crucial role as intermediary between the party and the voters, spreading the message of the political brand (Whiteley et al., 1994). Therefore this study seeks to examine how the internal market responds to the Conservative Party brand how they disseminate these messages to their local constituents. 
Using Kapferer's brand prism (2001) as our conceptual framework we examine the different facets of the Conservative brand from the perspective of the Conservative internal market. We provide some insight into the strengths of the communications strategy and how this has enhanced loyalty in the internal market. However, we also highlight the tension created by the hierarchical nature of what is seen an increasingly 'corporatized' Conservative brand. The paper seeks to show how thirteen years on the opposition benches has focused the Conservative Party leadership on rebranding their party and the extent to which the internal stakeholders buy into this 'modern' Conservative brand. We conclude by suggesting that rather than tightening the political brand there should be some latitude in the communications strategy to allow some local reinterpretation which will in turn enhance internal market loyalty.

\section{Branding Theory}

Although there are a number of definitions of a brand, Aaker's $(1996,7)$ definition focuses upon the brand as 'a distinctive name and or symbol', and is a differentiating feature in a competitive market. However, Knox (2004) takes this further and suggests that a brand is not only distinctive through its name or logo but it provides 'added value based on factors over and above its functional performance'. A brand is a communication device which represents the values, nature and personality of an organisation, product, service or political party (de Chernatony and McDonald, 2002; Jevons, 2005; Peng and Hackley, 2009).

Brands have been described as a 'cluster of values' (de Chernatony, 2001), multidimensional constructs (White and de Chernatony, 2002; Veloutsou, 2008), and also social objects (Muniz and O' Guinn, 2001) which are personally owned and embraced by the consumer (Neff, 2009). Hence brands imbue powerful symbolic values which create loyalty and, more importantly, an emotional attachment (Aaker, 1996; Fournier, 1998; Muniz and O' 
Guinn, 2001; Cova and Cova, 2002; Tan and Ming, 2003; Atkin, 2004; Algesheimer et al., 2005; Lindstrom, 2005; Lury, 2005; Lavine and Gschwend, 2006; Roper and Parker, 2006; Burnett et al., 2007). Paradoxically although brands are complex entities they need to be distilled into a simple, value-based message (Needham, 2005), that must be consistent both internally and externally and integrated in a coherent marketing strategy (White and de Chernatony, 2002). Hence a strong brand has a clear identity that resonates with the consumer, stakeholders and the internal market.

\section{Brand identity}

The notion of brand identity has been defined as the distinctive envisaged identity desired by the brand creator (Joachimsthaler and Aaker, 1997) which is supported by the internal stakeholders (Nandan, 2005; de Chernatony, 2006). Brand identity encapsulates the vision and aspirations of the brand which correspondingly has an effect on brand development (Alsem and Kostelijk, 2008). Brand identity has been broken down into six main components: vision; culture; positioning; personality; relationships; and presentation or reflection (Harris and de Chernatony, 2001; de Chernatony, 2002). These are all emotional components, however, Kapferer's (2001) brand prism also includes the more functional component of physique. Therefore, the brand prism generates a deeper understanding of a brand (Azoulay and Kapferer, 2003). Although brand identity prism is criticised for the authors' failure to conceptualise and operationalise the distinctions between the brand image and the brand identity concepts (Azoulay and Kapferer, 2003; Dahlen et al., 2010; de Chernatony, 2006; Harris and de Chernatony, 2001), it provides a mechanism to evaluate brand coherence and brand integration (de Chernatony, 2006). Indeed, 'a sense of identity and core values that underpin it provide an anchor around which all activities and communications can be structured'. Therefore, the brand prism, which represents a complex 
construct of brand identity (Dahlen et al., 2010), may enable a deeper understanding of the brand and in this instance the political brand.

On one hand, internal and external stakeholders are crucial when building a strong brand identity (Dean and Croft, 2001). On the other, for the brand to be perceived as authentic by external stakeholders, internal stakeholders have to believe in the brand's shared values (Harris and de Chernatony, 2001; Van Riel and Fombrun, 2007; Kapferer, 2001). Hence building a shared brand vision with internal stakeholders can only enhance brand identity.

\section{Internal branding}

The competitive nature of today's business environment has rendered tangible, functional benefits of a brand unable to sustain competitive advantage (King and Grace, 2010) and although a brand is a cluster of functional and emotional benefits (de Chernatony, 2001), the functional benefits can easily be copied. The skills and knowledge that people possess have been considered as valuable to an organisation. They represent the organisation's operant resources (Vargo and Lusch, 2004) that induce emotional benefits that provide the element of uniqueness and differentiation that a successful brand strives for (Papasolomou and Vrontis, 2006a). Indeed, because employees have direct contact with customers and other external stakeholders, they are the embodiment of the brand in the public's eyes (Wangenheim et al., 2007). Therefore, it is necessary that organisations provide their employees with an opportunity to understand their brand to enable them to deliver the brand promise. It is through their demonstration of positive brand-supporting behaviours that the brand can consistently transmit images to stakeholders which differentiate the organisation in the market place. This is crucial in a political marketing context particularly as the internal market members of a political party present the party message to the local community. As Edelman (1964) suggests 
meanings are not in the symbols. They are in society and therefore in men. Political symbols bring out the concentrated from those particular meanings and emotions which the members of the group create and reinforce in each other.

Hence, political brand identity is co-produced by the party elite, media and also the citizens but should be reinforced by the internal market when presenting this to the local constituents.

Recently, marketing researchers and practitioners have focused on internal branding as a means to enable an organisation to fulfil its brand promise proposed to external constituencies (e.g. Drake et al, 2005; Mitchell, 2002). A number of studies (e.g. King and Grace, 2010; Miles and Mangold, 2004; Punjaisri et al., 2009) have supported the notion that internal branding enables employees to develop a shared understanding and necessary skills that allow them to effectively 'live' the brand and become 'brand Evangelists' (Nandeem, 2007). Such positive outcomes of effective internal brand management such as enhanced employees' brand commitment (Aurand et al., 2005; Burmann and Zeplin, 2005), brand loyalty (Papasolomou and Vrontis, 2006b), and brand identification (Punjaisri and Wilson, 2007) have been empirically documented. It is through these positive attitudes that employees have towards brand that subsequently engender brand-consistent behaviours (Punjaisri et al., 2009). By securing management's understanding and commitment, employees will better accept and internalise brand values, resulting in a better alignment between their attitudes and behaviours, and the brand (Vallaster and de Chernatony, 2006). Consequently, they can act and behave naturally when delivering the brand promise at any brand touch points (Mosley, 2007). In political campaigning, galvanising the internal market so they can convey the political brand to voters is a crucial component of electoral strategy.

Internal branding requires support from a communication strategy that takes account of both external and internal communication practices (Hallam, 2003). According to Bergstrom 
et al. (2002), internal branding should focus on effectively communicating the brand to employees and convince them of their worth and relevance to the delivery of the brand promise. Therefore, internal communications become an integral element of internal branding, reflecting the marketing input into the internal branding process. Indeed, Terry (2003) has argued that marketers can add credibility to internal communications, this is because of their knowledge about peoples' motivation, needs, desires, and weaknesses; they are capable of not only communicating the brand but also shaping people's perceptions. Various authors have viewed internal communications as an effective motivation mechanism (e.g. Piercy, 1995; Rafiq and Ahmed, 1993), having the capability to reduce employee resistance in times of change (Foreman, 2000). Zucker (2002) argues for internal communications as being the first point of focus in internal branding to induce employee's commitment and encourage behavioural changes. Indeed, Punjaisri and Wilson (2007) have found that internal communications exert a relatively higher effect on employees' brandsupporting behaviours than training programmes do, although they have contended that the coordination between Marketing and HR is essential in internal branding.

In order to optimise the effectiveness of internal communications, authors (e.g. Henkel et al., 2007; Wood, 1999) have highlighted the balanced management of both formal and informal communications. Furthermore, an open environment, a two-way communications process is pivotal when building mutual understanding and trust between managers and employees within and across departments (Sonnenberg, 1991; Varey, 2005). This can build up to four times higher employee satisfaction and twice their commitment (Higgins, (1996). For activists and party members who are largely voluntary, satisfaction and commitment are central to their engagement (Capato, 2008; Parry et al., 1992). This section discussed the theoretical concepts of branding in particular brand identity and internal branding the next section will examine these constructs from a political perspective. 


\section{Political branding}

Branding has been applied to destinations, countries, cities, stately homes (Adams, 2010; Bily, 2008; Morgan, et al., 2002; Robinson, 2004; White and de Chernatony, 2002), as well as for religion, sports teams, rock bands, people (Einstein, 2008), universities and the metropolitan police. More recently there has been an emerging interest in applying branding concepts to politics (White and de Chernatony, 2002; Lees-Marshment, 2009; Lilleker, et al., 2006; Moufahim and Lim, 2009, Phipps et al., 2010; Reeves et al., 2006; Smith, 2009;), but as Harrop (1990) pointed out the nature of governing is much like a service provider in that it is intangible, complex and heavily reliant on people. This services perspective of political parties was supported by Henneberg and O'Shaughnessy 2007, who argued that there are three components of the political brand, firstly policy as the service offering, secondly the politician as the tangible service offering and the party as the brand offering.

Nevertheless voters elect the party they believe to be most capable of providing those services (Butler and Stokes, 1969; 1974; Clarke et al., 2004) but as Lock and Harris (1996) pointed out in their seminal paper political parties are 'complex intangible products which the voter cannot unbundle [so]...vvoters have to judge on the overall packaged concept or message'. Therefore during an election campaign political parties position or reposition themselves through the development of policies that resonate with their target group (LeesMarshment, 2009). Over time re-positioning is necessary in order for the party or candidate to adapt to environmental or market trends but this is largely constrained by the party history, ideology and their record on promise delivery (Worcester and Baines, 2006). This is where the notion of branding is helpful to political parties as it can provide a framework for presenting their values, vision and strategy for achieving that vision, in short it can be a very efficient heuristic device. However, this vision needs to be shared by all stakeholders but in 
politics it is more complicated as political parties are 'complex organisations with multiple levels, sites of authority and goals' (Bale, 2008). The hierarchical nature of political parties with party members, Members of Parliament and the leadership create a dynamic tension on the development and consistency of the political brand. Leadership is crucial and can affect how the brand is perceived by voters. Peng and Hackley $(2009,174)$ claim that not only can branding be applied to political parties it can also be applied to political candidates and leaders which 'build[s] a sense of reassurance and foster[s] identification", conversely, the party leader can also create dissonance amongst voters (Scammell, 2007). Hence this paper will attempt to unbundle the key characteristics of the Conservative brand identity and this may go some way in explaining how the Conservative Party only partially succeeded in getting into power after the UK 2010 General Election campaign.

\section{The Conservative Party}

The Conservative party has a strong tradition in the UK as one of the oldest political parties, the origins can be traced back to the seventeenth century (Norton 1996; Charmley, 1996; 2008; Blake, 1989). During the last century it was the most successful party in the UK (Denham and O'Hara, 2007; Lloyd, 2006) and has been seen as the natural party of government of the United Kingdom (Willetts and Forsdyke, 1999). However, this masks an underlying tension that runs through the Conservative Party, which has been present since the 1832 Reform Act and the repeal of the Corn Laws. This tension is two dimensional; firstly there are two factions within the Conservative Party who differ on one key dimension, namely the authoritarian/liberal dimension. This is exemplified by traditional/protectionist and progressive/free trade and, although the party's core value is to conserve, these two factions differ in how conservation is conceived, managed, and how it provides the vision for governance (Charmley, 1996). This key distinction still affects Conservative thought on issues such as society, the tension between the rural and urban constituencies (Woods, 2002), 
acceptance to change, law and order, wealth creation, and role of government, the state and institutions (Hickson, 2005; Kavanagh, 2000; Norton, 1996). This factional distinction also affects the Conservative perception of the UK and its position in the world, particularly its vexed relationship with Europe (Crowson, 2006, Lynch, 2009). Secondly, there is a tension between 'visceral Conservatism and political necessity' (Charmley, 2008, 3), the distinction between ideology and pragmatism. This affects how the Conservative Party relates to power, the mechanisms used to gain power and the rhetoric of persuasion. In summary, the picture painted of the Conservative Party is one of a complex collection of beliefs and values that have been created historically, occasionally ideologically and often pragmatically.

For some, the reason for the enduring success of the Conservative Party during the twentieth century was the notion of moderation (Blake, 1997), a post-war consensus with a centre right focus. This moderation is evident in many Conservative Governments from Churchill to Heath; however, moderation was not what the Thatcher government was noted for. After Thatcher's demise there were a series of Conservative Party leaders, only Major succeeded in winning a General Election, the rest - Howard, Duncan-Smith, Hague all presided over a 'sales led' Conservative Party (Lees-Marshment 2004) on the Opposition benches whilst Blair's new Labour were in power.

This brief historical analysis sets the scene for the situation David Cameron inherited when he became Conservative Party leader, his aim was to diminish their 'Nasty Party' image famously described by Theresa May. Research conducted by Lord Ashcroft (2005) found that 'the Conservative party doesn't stand for anything anymore' (Ashcroft 2005, 93) but crucially he believed that 'millions of people thought the Conservative Party wasn't like them and didn't understand them; the problem is that they were right'. The Conservative brand had become 'toxic' and it was Cameron's role to decontaminate it (Jones, 2008, 3). 
Denham and O'Hara (2007) note that 'what an opposition can do: prepare for office, seek to present itself as a credible alternative to the government and exploit opportunities when they arise'. Cameron's repositioning of the Conservative brand was an attempt to present a credible, electable alternative and this meant that the new branding strategy had to be accepted by party members, who would in turn, reinforce the brand values and create a coherent brand identity. This was the message learned by new Labour who during the 1997 UK General Election campaign ensured all political activities and communications were 'on message'. The Conservative brand needed to be synchronised internally, in order to present consistent image to external stakeholders including the electorate, the media and other interest groups such as business, (Harris de Chernatony, 2001; Van Riel and Fombrun, 2007, Dean and Croft, 2001). This paper examines how the internal Conservative stakeholders accepted the David Cameron's Conservative brand image through the conceptual framework of Kapferer's brand prism.

\section{Methodology}

This paper seeks to examine the Conservative Party brand from the perspective of the internal stakeholders, thus building an understanding of Conservative brand identity. Political branding research is at the exploratory stage (Lees-Marshment, 2009; Smith, 2009), and Davies and Chun (2002) suggest that qualitative research is useful at the early stages of a relatively under researched area. The methodology aims to take an 'inside-out' approach to the Conservative Party brand (Harris and de Chernatony, 2001; Peng and Hackley, 2009; Van Riel and Fombrun, 2007). By understanding how the internal stakeholders conceive the brand it is possible to identify where problems arise and where they can be ameliorated. With this in mind this paper adopted a qualitative research approach using in-depth semistructured interviews in order to understand the UK Conservative brand from the perspective of internal stakeholders (Gillham, 2005; Warren and Karner, 2005). In-depth interviews 
often seen as 'special conversations' (Rubin and Rubin, 1995, 6), can be seen as flexible in terms of topic area development, spontaneous and 'potentially a Pandora's box generating endlessly various and abundant data', (McCracken, 1988, 12). A judgement sample was adopted and this generated a sample size of 30 internal Conservative stakeholders including Members of the European Parliament, House of Commons and House of Lords, Councillors, activists, and Prospective Parliamentary Candidates. Interviews were conducted prior to the 2010 UK General Election; December 2009-April 2010. Each interview was tape recorded and fully transcribed for analysis. There are a number of issues that qualitative researchers face when conducting research, most notably validity, generalisability, access and consent, reflexivity, voice and transparency (Butler-Kisber, 2010, 13). These issues were considered throughout the research design, data collection and analysis process. The validity of this paper is, thus, based on the quality of interviews and findings interpretation in relation to extant literature. The thematic enquiry was adopted following the approach of Bird et al. (2009: page number?),

the initial categories were modified from a broad and culturally appropriate list...following the first round of coding, categories were broken into subcategories by identifying properties that described the content of each category

Drawing on authors such as Kvale (1996), Rubin and Rubin (1995) and Heath and Heath (2008), the transcripts were examined using Kapferer's brand prism (2001) as a conceptual framework.

Figure 1 should be placed here

Therefore, the findings are organised into the categories physique, relationship, reflection, personality, culture and self image. Using these facets this study builds an 
understanding internal market's engagement with the repositioned Conservative brand identity.

\section{Findings}

\section{Conservative Party Physique}

Einstein $(2008,12 / 3)$ argues that in terms of successful branding 'the name or the logo appears on everything that is associated with that brand comes to mind'. Within the conceptual framework of Kapferer's brand prism the physique is the functional aspect of the brand identity, for de Chernatony (2006) it refers to the tangible elements of a brand. Many respondents were ambivalent about the change in visual identity, one party member pointed out that they

quite liked the torch but was tied to specific aspects - Mrs. T [Thatcher]...so time for a change

Another councillor believed that

the torch was more strident. The torch represented the part of Margaret Thatcher; it was a strident, strong symbol. It represented Britain in the world going forward. The tree is an eco; we jumped on the eco band-wagon - vote blue, go green - I don't agree with it. I am not an eco person at all.

A further councillor argued that they 'ignore' the new oak tree logo and apart from it goes on the ballot papers, I have completely ignored it. Why? I dislike it, I don't understand it.

Other comments followed a similar viewpoint suggesting that they 'don't fly the Tory colours' in their constituency and consider the blue and green oak tree as 'dull and boring', (MP), instead have their own colours and established identity. If the logo was ignored so were central policies as one MEP claimed to

campaign very much on broadly local issues and on the reputation of being independent minded...in politics what matters is your reputation and you have to establish that from day one.

This tension between central and local party identity has affected the consistency of the 'modern' Cameron Conservative brand. 


\section{Conservative Party Relationship}

The relationship facet of the brand prism is described as the relationship between the brand and the consumer, and the brand and the internal market (de Chernatony, 2006; Kapferer, 2001). For a political party this can be explained through a) voter attitudes, (an external perspective that beyond the scope of this paper), b) structural nature of the party, the party leadership and the internal market and c) the emotional sense of belonging to the brand.

Figure 2 should be placed about here

The structure of the Conservative Party comprises of three elements; the Parliamentary Party, Professional Party and the Voluntary Party where there is some degree of overlap. Members of Parliament belong to the Parliamentary Party; the Professional section includes local councillors, representatives and Prospective Parliamentary Candidates; whilst regional associations, volunteers, activists and sub-groups make up the Voluntary section. There was a broad consensus from the internal stakeholders that there is a distinction between the Parliamentary (Central) Conservative Party and the Regional Conservative brand in terms of the values, outlook and traditions. However it was also suggested that each region or association could have its own identity yet still hold Conservative Party brand values.

The relationship between the party leadership and the local/European Parliamentary members has raised some concerns of accelerated centralisation of the Conservative Party message. It was suggested by some that the Parliamentary Party has taken away powers from the local/European level leaving some to concur that 'the party has become too centralised' (MEP) whilst another MEP claimed that they 'regretted the way we are obliged to centralise our organisation and campaigning'. This is further illustrated by a local party member when 
he claimed that there was 'more power to grass-roots in my day...all areas had power, more of a community themed party'. Another local party activist claimed that the Party had 'everything comes from CCHQ [Conservative Party Central Head Quarters]...and Conservative Associations are resenting this being told what to do'.

Centralisation of the Conservative branding strategy has put a strain on the internal market relationship, as one party member commented 'The central [Parliamentary] party needs to trust local associations and regional levels of the party more...the electorate trusts us but this sense of trust is missing between the central and local parts of the party'.

There was little understanding or acceptance of the need to have a consistent message, particularly in today's instant media environment. Several participants were disgruntled that the Conservative Party did not appear to echo the concerns of citizens outside Westminster. Some stated that even Conservative stakeholders are not totally 'convinced' or comfortable with policies and approaches adopted by the Parliamentary Party, 'The further you go away from London and in other parts of the country; I don't think it is resonating as good' (party member).

A number of participants of the Conservative Party regions and MEPs felt that there was a 'them and us' mentality with many feeling 'disconnected' from Westminster. One MEP stated that there have 'always been problems between the Parliamentary Party and the European Conservative Party'. Nevertheless, they still see themselves as Conservatives but the locus of control is firmly at with the Parliamentary Party. The literature reflected a consistent coordinated message but one councillor believed that the local publicity material was more successful, he claimed that

when centralised Conservative literature is given out during campaigning many people say no I don't think I am going to vote Conservative. When 
given the locally branded literature citizens have replied oh I will definitely vote for you - we get loads of those through the door.

For some, the Conservative brand it was a modern political party, offering something for everyone in terms of policy and values, in-tune with modern. This point was shared with a Prospective Parliamentary Conservative Candidate who believed that the Conservatives were

a lot more unified - all harmonised over big issues...brought new blood into the party from different backgrounds...good team in place...good policy.

It appears that there are constituency members who have promoted their own version of the Conservative brand whilst sitting comfortably under the UK Conservative Party banner. They are fiercely loyal Conservatives who are loyal to the fundamental core Conservative values of responsibility, freedom, aspiration and individualism and used these values as a structure for dealing with the issues facing their local constituents.

However, during the course of the interviews it emerged that there were tensions between different elements of the Conservative Party in terms of trust, personal support and values. Members of the European Parliament considered that there was an indifferent relationship between the Westminster Conservative Party and the European Conservative Party. A number of participants of other elements of the Conservative Party including the professional and voluntary strands still considered a 'them and us' mentality, and the feeling of being 'disconnected' from the Westminster bubble.

Many were also not entirely convinced with the direction the Conservative Party was going and there was a distinct lack of trust of Central Office leading to a lack of support from many constituency members. One Conservative councillor, although conceding that branding was an important concept, he questioned who

controls the brand...we make the brands in the provinces...we don't have to buy into it... Obviously the tree [logo] was chosen by Dave's henchmen in central office and if tomorrow they chose to have a venetian clock tower [as 
their logo] that's what we will have, that's their choice. In that sense they are the centre - the corporate Conservative Party.

This was a recurring theme throughout the interviews with many respondents, particularly those outside Westminster, resisting any attempts at controlling the message and the brand. This was also reflected in the next section of culture and reflection.

\section{Conservative Culture and reflection}

Culture is described by Kapferer $(2001,101)$ as 'the set of values feeding the brand's inspiration'. For the respondents interviewed, the core Conservative values of responsibility, freedom, aspiration and individualism which are interpreted and operationalized at Constituency level. This view was shared by a Conservative Member of Parliament who suggested that 'the party has distinct characteristics in different parts of the country...the party reflects the character of the place' (MP).

One MP went further stating that the Conservative Party in their part of the UK was 'ten years behind the game...more traditional' than the Conservative Party in the South of England and the Parliamentary Party. There was a view that the local party needed to respond to local beliefs and values for instance, one Prospective Parliamentary candidate commented 'Distinction is nothing new. A provincial Northern seat...can only win by showing clearly you have got sort of a local identity.'

This local interpretation of Conservative values was a recurring theme throughout the interviews for instance, another councillor suggested that

Each region of the Party [Conservative] has their own identity and promotes different forms of conservatism.... We reflect the local needs filtered through our party agenda but tailored from the dining a la cart of the menu of the best issues... whether it is urban, suburban or rural. We are all dining from the big book of recipes but the menu's we are choosing to dine off are different albeit all put together by the same master chef Dave. 
In the marketing literature it is argued that consistency is key to a strong brand this is also true for political brands according to Schneider (2004). However, local interpretation of these values is evident in the Conservative safe seats where a consistent, tailored message continues to resonate with the local electorate.

\section{Conservative Personality}

Personality is described as the figurehead or spokesperson for the brand (de Chernatony, 2006; Kapferer, 2001). For the leader there was a view that David Cameron had

great integrity, had a generosity of spirit and I liked his values and I liked his positive view on the world. It's not an angry philosophy basically an enabling philosophy.

One curious aspect is that although there was a view that Cameron was centrist in terms of Conservative policymaking he was seen by some as being very keen to localise politics, to give decisions back to local people. He was seen as very keen to reduce the size of the state again empowering people to take charge of their own lives within their own communities (PPC). For one MP Cameron was a curious mix of traditional/liberal Conservative, 'you can trace him back to MacMillanite-Disraelite with a touch of Gladstone - the only thing he didn't have a ideological tap into was Thatcher in a funny way' almost 'all things to all Tories'. He was also seen as being a good communicator who espoused the virtues of the 'one-nation' Conservatism, he was also perceived to be 'sincere' (MP) and 'keeps his cool' under pressure (Member House of Lords). One respondent suggested that as he was an unknown quantity, he had no baggage so 'determined to succeed and repackage the Party plus presenting himself doing it'. He believed he would be successful in attracting the middle classes who had defected to new Labour by 'the huskie, the goodies, the greenery, the socially inclusive, trendy, Notting Hill sort of approach'. One key point raised by one respondent is that 'David Cameron has transformed the standing of the party that people are 
prepared to listen to $u s^{\prime}$. So after three election defeats the majority of participants were willing to support Cameron as they could see 'he's a winner', 'electable' and they were 'sick of losing' and this was the 'best chance of re-election for a generation'.

\section{Self Image}

Self image refers to the way "in which a brand enables users to make a private statement to themselves" (de Chernatony, 2006, 212). As the internal market are consumers of the Conservative brand this will be examined rather than the views of external stakeholders. There was a high level of inconsistency amongst respondents regarding the extent to which the brand had changed. Moreover, for those who believed the brand had changed there a diversity of views as to how the brand had changed and what the catalyst was for change. For many respondents, like this Conservative Future member, the facade of the Party had changed under the leadership of David Cameron but in reality the Party was still the same as it was under the leadership of Michael Howard. This was reflected in comments from party members who were sceptical about the extent to which Cameron could change the party for instance one remarked that 'The MPs haven't changed so how can the party have changed...if Cameron wins and after the honeymoon period the veneer will peel off'. Another suggested that "the values [of the Conservative Party] are still the same but the perception of leadership has changed'. Many respondents supported this view arguing that the Conservative Party was focusing on 'style' of the message rather than 'substance' of policies.

Contrasting this view, there was a significant proportion of interviewees who believed that the Conservative Party had changed under Cameron's leadership 'he has changed it, he has softened it, he's chosen quite a few what he believes to be popular elements and the whole green agenda - I think he truly believes in' but the clarity of the message was missing. It was 'too vague'; Cameron had 'changed the look [of the Party] but did not do enough with 
the message...it's not clear what they stand for'. One MEP suggested that David Cameron 'hasn't made enough of a change' arguing that the Conservative Party needed more 'substance'.

For many respondents substance meant that the electorate understood what the Conservatives stood for compared to Labour, for instance one MP was worried that 'we don't have a clear distinction...no differentiation...we need to get that back...I don't think we have any clear values'. The concern for a clear message that distinguished the Conservative Party from the alternatives was also evident amongst the voluntary party members one suggested, 'we haven't put across a clear alternative'.

A number of participants were unsure about the Conservative brand and we don't really know what the central party stands for and Dave is not clear too', (Councillor). 'do not know what Dave's purpose or central idea is yet' (MP). When asked to clarify their confusion it was again claimed that the Conservative Party's message was not clear enough, which was confusing not just the participant but also the electorate. A handful of participants were concerned that the Party itself didn't fully understand the message it was trying to project and didn't know the core values of the Conservative brand despite the General Election being only months away. This was reiterated by a member of the Professional element of the Conservative Party revealed that many members of the Party including CCHQ didn't understand the envisaged identity and 'if $\mathrm{CCHQ}$ don't understand their brand what hope can we have for the rest of the country'.

Despite this lack of clarity for the Conservative brand identity of this one MEP reacted pragmatically and claimed to 'campaign very much on broadly local issues and on the reputation of being independent minded...in politics what matters is your reputation and you have to establish that from day one'. Indeed, as advocates of the brand or brand evangelists 
they need to be on message supporting the Cameron Conservative brand. However, some respondents argued that it was their personal relationship with the local electorate that was responsible for their success hence we have two physical manifestations of the brand, the Party leader but also the local MP. This was particularly evident in the safe seat constituencies and the local MP empathised with the needs of the area in terms of business, economy and local people.

There was a belief that Cameron may be the best chance for electoral success for some time so many kept their reservations quiet and went along with what he was doing; although he was changing the perception of the Conservative brand he wasn't going to change their beliefs. Cameron has merely 'quietened the dissatisfaction and united around the fact we need to shut up and win', (Councillor) as 'You can achieve nothing in politics if you don't win elections' (Councillor). Finally it appeared that being on the opposition benches for 13 years, many respondents concluded 'we are all willing to shut up to get Cameron elected', (MEP), 'we can't go on like this' (MP), and 'it's time to keep quiet and get elected' (party member).

\section{Conclusion}

In terms of communicating the values of the brand, the findings clearly indicate that the Conservative Party still does not have a clear brand identity within the internal market and demarcation lines follow the historical strands within the Conservative Party. Furthermore there are clear distinctions between the national and local Conservative brand and how this is presented to the citizen by local campaigners. This notion of central and local message differentiation is quite a dilemma for Central office, there is a need to respond to local issues to act local but it needs to be underpinned by a central core message. Although if more control that goes to the local constituency there is a chance that the message may become more diluted and this could undermine the Conservative brand. This dilemma is not new, nor 
necessarily problematic. Anthony Downs (1957:135) in his seminal work argued exactly this when he discussed appealing to rural and urban constituencies with different policies that were not conflicting. The crucial aspect of building a political brand is that it must contain core values that are consistent with the ideology, values, history and culture of the party and the leader embodies this through their own interpretation of Conservative values. The importance of the local constituencies are to operationalise this Conservative brand, through peripheral values that resonate with the core values but are more flexible identifying specific values that echo the local constituency reflecting the culture and circumstances of the local constituency electorate. Vallaster et al. (2006) argue that internal stakeholders play a crucial role in promoting a successful brand, with a strong identity that has the potential of instilling and maintaining confidence with the consumer or citizen (Schneider 2004).

Wagenheim et al. (2007) suggest that the key strengths of the internal market are the skills and knowledge of the local market and the enthusiasm and the motivation they have for the brand demonstrate they are the 'embodiment of the brand' (Wagenheim et al. (2007). In terms of brand supporting behaviours and a shared understanding there is still some dissonance here, internal communications need to reveal a consistency with the local party values and Cameron's Conservative brand.

\section{Implications}

The implications arising from this study focus upon firstly the use of Kapferer's brand prism. This conceptual framework was useful for building an in-depth understanding of the Conservative brand and unearthing the challenging aspects the brand is experiencing. In particular, the culture and the relationship facets of the brand prism raised the most concerns. For instance the past failures of the Conservative Party which have been due to poor strategic decisions which were short term and sales led (Lees-Marshment 2004); disunity in a number 
of guises (Norton 2009), for instance splitting the rural vote Woods (2002); Europe (Lynch 2009); and finally the legacy of Margaret Thatcher (Butler and Kavanagh 2002). The 'them and $u s^{\prime}$ mentality identified in this study suggests that there is a lack of message consistency across the internal stakeholders of the party. An ineffective implementation of internal branding inside the party is reflected by the lack of shared vision, and resistance to change of some internal audiences. Indeed, the call for a clear message of what the brand stands for further highlights the significant role of internal branding to clearly communicate with the internal market about its brand identity. As a result, there is evidence of resistance to change from some party members. Without a shared understanding of brand identity, it is unlikely that external audiences receive a coherent brand message at all brand touch points (e.g. Punjaisri et al., 2009). Secondly, although this research paints an interesting picture of the internal Conservative brand there are serious implications arising from the contradictions and uncertainty about the Conservative brand. Whilst David Cameron is considered the personality of the brand identity prism, the perceived lack of the management's understanding and commitment explains the issues found in the culture and relationship dimensions. This highlights that all dimensions of the brand prism are distinctive, yet interdependent and internal branding cannot be effective without first securing the understanding and commitment from the party leadership members. Also, this study encourages management to implement open-environment, two-way communications in order to build mutual understanding and trust across the political party. When trust exists across the internal audiences, internal branding becomes more effective in enhancing the party members' commitment and loyalty (Mohart, Herzog and Tomczak, 2009). However, our research suggests that the historical hierarchical nature of the Conservative Party is partly to blame. During and after the Thatcher era much of the traditional elite power structure was replaced with more accessible institutional processes, many respondents were concerned 
about the return to an elite power structure under the leadership of David Cameron. This affects how internal market engagement is not only developed but also how internal communications are managed and it is communicated. From this research it is clear that there still remains an unswerving loyalty to the Conservative Party amongst the participants of this study. The enthusiasm and loyalty that exists amongst the party activists who continue to be 'Brand Evangelists' for the Conservative Party needs to be harnessed and not viewed with apprehension.

\section{References}

Aaker, D. (1996). Building Strong Brands. London: Simon \& Schuster.

Adams, S. (2010). 'Reborn, the splendour of Chatsworth', The Daily Telegraph, March $12^{\text {th }} 2010,7$.

Alsem, K. J. and E. Kostelijk. (2008). "Identity based marketing: a new balanced marketing paradigm.” European Journal of Marketing 42 (9/10): 907-914. doi:10.1108/03090560810891064

Ashcroft, M. A. (2005). Wake up and smell the coffee. A Wake-up call for the Conservative Party, London: Ashcroft.

Aurand, T. W., L. Grochels and T. R. Bishop. (2005). "Human resource management's role in internal branking: an opportunity for cross-functional brand message synergy." Journal of Product and Brand Management 14 (2): 163-169. doi:10.1108/10610420510601030.

Baines, P. (1999). "Voter Segmentation and Candidate Positioning." In Handbook of Political Marketing, edited by B. Newman. Thousand Oaks CA: Sage.

Bale, T., (2008), "A Bit Less Bunny-Hugging and a Bit More Bunny-Boiling? Qualifying Conservative Party Change under David Cameron." British Politics 3: 270-299. doi:10.1057/bp.2008.7.

Bergstrom, A., D. Blumenthal and S. Crothers. (2002). "Why internal branding matters: the case of Saab". Corporate Reputation Review 5 (2/3): 133-142.

doi:10.1057/palgrave.crr.1540170.

Bily, W. (2008). "Creating the Customer Experience, American Banking Association." Banking Journal 100 (6). 63.

Blake, R. (1989). The Conservative Party from Peel to Thatcher. London: Methuen.

Boyle, E. (2007). "A process model of brand co-creation: brand management and research implications." Journal of Product \& Brand Management, 16 (2): 122-131. doi:10.1108/10610420710739991.

Brams, S. (1985). Rational Politics, Decisions, Games and Strategy. San Diego: Academic Press.

Burmann, C. and S. Zeplin. (2005). "Building brand commitment: a behavioural approach to internal brand building." Journal of Brand Management 12 (4): 279 - 300. doi:10.1057/palgrave.bm.2540223.

Burnett, J. and R. B. Hutton. (2007). New Consumers need new brands, Journal of Product and Brand Management 16 (5): 342-347. doi:10.1108/10610420710779636. 
Butler, D. and D. Kavanagh. (2002). The British General Election of 2001. Basingstoke: Palgrave McMillan.

Cameron, D. (2010). "My Vision, Your Choice." The Daily Telegraph, April $3^{\text {rd }}$ 2010, 25.

Campbell, J. (2008). "In defence of David Cameron: How the Tories have gotten past soul searching in opposition." Review - Institute of Public Affairs 60 (1): 33.

Capato, R. K. (2008). "Religious capital and intergenerational transmission of volunteering as correlates of civic engagement." Nonproft and Voluntary Sector Quarterly 38 (6): 983-1002. doi:10.1177/0899764008323990.

Charmley, J. (1996/2008). A History of Conservative Politics. London:Palgrave Macmillan.

Clarke, H. D., D. Sanders, M. C. Stewart and P. Whiteley. (2004). Political Choice in Britain. Oxford: Oxford University Press.

Cova, B. and V. Cova. (2002). "Tribal marketing: The tribalisation of society and its impact on the conduct of marketing. ” European Journal of Marketing 36 (5/6): 595-620. doi:10.1108/03090560210423023.

Creswell, J. W. (2007). Qualitative Inquiry and Research Design. London; Sage Publications Ltd.

Davies, G. and R. Chun. (2002). "Gaps between the internal and external perceptions of the corporate brand." Corporate Reputation Review 5 (2/3): 144-158. doi:10.1057/palgrave.crr.1540171.

de Chernatony, L. (2001). "A model for strategically building brands." Journal of Brand Management 9 (2): 32-44. doi:10.1057/palgrave.bm.2540050.

de Chernatony, L. (2002). "Would a brand smell any sweeter by a corporate name?" Corporate Reputation Review 5 (2/3): 114-132. doi:10.1057/palgrave.crr.1540169.

de Chernatony, L. (2006), From Brand Vision to Brand Evaluation. Oxford; ButterworthHeinemann.

de Chernatony, L. and M. McDonald. (2002), Creating Powerful Brands, Oxford; Butterworth-Heinemann.

Dean, D. and R. Croft. (2001). Friends and Relations: long term approaches to political campaigning, European Journal of Marketing 35 (11/12): 1197-1217. Doi:10.1108/EUM0000000006482.

Denham, A. and K. O'Hara. (2007). “The Three 'Mantras: 'Modernisation' and the Conservative Party.” British Politics 2, 167-190. doi:10.1057/palgrave.bp.4200057.

Dinnie, K. (2008). Nation Branding: Concepts, Issues, Practice. Oxford: ButterworthHeinemann Elsevier Ltd.

Drake, S. M., M. J. Gulman and S. M. Roberts. (2005). Light Their Fire. Chicago: Dearborn.

Einstein, M. (2008). Brands of Faith: Marketing religion in a commercial age. Oxon: Routledge.

Foreman, S. K. (2000). "Get close to the internal customer or keep your distance?" In Internal marketing directions for management, edited by R. J. Varey and B. Lewis. London: Routledge.

Fournier, S. (1998). "Consumers and Their Brands: Developing Relationship Theory in Consumer Research.” Journal of Consumer Research 24 (4): 343-373. doi: 00935301/98/2404-0001.

Gillham, B. (2005). Research Interviewing: the range of techniques. Berkshire: Open University Press.

Gould, P. (1998). The Unfinished Revolution. How the modernisers saved the Labour Party. London: Little Brown and Co. 
Hallam, R. (2003). Delivering the brand promise at Washington Mutual. Strategic Communication Management, 7 (4):18-21.

Harris, F. and L. de Chernatony. (2001). "Corporate branding and corporate brand performance." European Journal of Marketing 35 (3/4): 441-456.

Doi:10.1108/03090560110382101.

Harrop, M. (1990). "Political Marketing." Parliamentary Affairs 43 (3): 277-291.

Heath, M. T. P. and M. Heath. (2008). "(Mis)trust in Marketing: a reflection on consumers' attitudes and perceptions.” Journal of Marketing Management 24 (9-10): 1025-1039. doi10.1362/026725708X382037.

Helm, T. (2010), "Cameron to pledge NHS cash boost for poorest." The Observer, January $3^{\text {rd }}, 1-8$.

Henkel, S., T. Tomczak, M. Heitmann and A. Herrmann. (2007). "Managing brand consistent employee behaviour: relevance and managerial control of behavioural branding." Journal of Product and Brand Management 16 (5): 310-320. doi.org/10.1108/10610420710779609.

Henneberg, S C. and N. O'Shaughnessy. (2007). "Prolegomena to Theory and Concept Development in Political Marketing." Journal of Political Marketing, 6 (3): 1-4. doi:10.1300/J199v06n02_01.

Hickson, K. (2005). The Political Thought of the Conservative Party since 1945. Hampshire; Palgrave Macmillan.

Higgins, E. T. (1996). "Knowledge activation: accessibility, applicability and salience". In Social Psychology: Handbook of Basic Principles, edited by E. Higgins and A. Kruglanski. New York, NY: Guilford. 133-168.

Jevons, C. (2005). "Names, brands, branding: beyond the signs, symbols, products and services." Journal of Product and Brand Management 14 (2/3): 117-118. doi:10.1108/10610420510592590.

Joachimsthaler, E. and D. A. Aaker. (1997). "Building brands without mass media." Harvard Business Review 75 (1): 39-50.

Jones, D. (2008). Cameron on Cameron: Conversations with Dylan Jones, London: Harper Collins Publishers.

Kapferer, J. (2001). Strategic Brand Management, London: Kogan Page Ltd.

Kavanagh, D. (2000). British Politics: Continuities and Change. Oxford: Oxford University Press.

King, C. and D. Grace. (2010). "Building and measuring employee-based brand equity." European Journal of Marketing 44 (7/8): 938 - 971. doi:10.1108/03090561011047472

Knox, S. (2004). "Positioning and branding your organisation." Journal of Product and Brand Management 13 (2/3): 105-115. doi:10.1108/10610420410529735.

Kvale, S. (1996). An Introduction to Qualitative Research Interviewing, London: Sage.

Lavine, H. and T. Gschwend. (2006). "Issues, Party and Character: The Moderating Role of Ideological Thinking on Candidate Evaluation.” British Journal of Political Science 37 (1): 139-163. doi:10.1017/S0007123407000075.

Lee, S. and M. Beech. (2009). The Conservatives Under David Cameron: Built to Last? Hampshire: Palgrave Macmillan.

Lees-Marshment, J. (2004). "Mis-marketing the Conservatives: The Limitations of Style over Substance.” Political Quarterly 75 (4): 392-397.

Lees-Marshment, J. (2009). Political Marketing: Principles and Applications, Abingdon: Routledge. 
Lilleker, D. G. N. A. Jackson and R. Scullion. (2006). The Marketing of Political Parties: Political Marketing at the 2005 British General Election. Manchester: Manchester University Press.

Lloyd, J. (2006). "The 2005 General Election and the emergence of the negative brand". In The Marketing of Political Parties: Political Marketing at the 2005 British General Election, edited by D. G. Lilleker, N. A. Jackson, and R. Scullion. Manchester: Manchester University Press.

Lock, A. and P. Harris, P. (1996). "Political Marketing - vive la difference!" European Journal of Marketing 30 (10/11), 21-31. Doi:10.1108/03090569610149764.

Lury, C. (2005). Brands: The Logos of the Global Economy. Abingdon: Routledge.

Lynch, P. (2009). "The Conservatives and the European Union: The Lull Before the Storm". In The Conservatives under David Cameron: Built to Last? edited by S. Lee and M. Beech. Hampshire: Palgrave McMillan.

McCracken, D. (1988). The Long Interview, London; Sage.

Miles, S. J. and G. Mangold. (2004). "A conceptualization of the employee branding process." Journal of Relationship Marketing 3 (2/3) 65-87. doi:10.1300/J366v03n02 05.

Mitchell, C. (2002). "Selling the brand inside." Harvard Business Review 80 (1): 99 - 105.

Morhart, F. M. W. Herzog and T. Tomczak. (2009). "Brand-specific leadership: Turning employees into brand champions." Journal of Marketing 73 (5): 122-142. doi:10.1509/jmkg.73.5.122.

Morgan, N. A. Pritchard and R. Piggott. (2002). "New Zealand, 100\% Pure. The creation of a powerful niche destination brand." Journal of Brand Management 9 (4/5): 335354. doi:10.1057/palgrave.bm.2540082.

Morris, N. (2009). "Battle for pink vote gets poisonous." The Independent, July $4^{\text {th }}, 8-9$.

Mosley, R. W. (2007). "Customer experience, organisational culture and the employer brand." Brand Management 15 (2): 123 - 134. doi:10.1057/palgrave.bm.2550124.

Moufahim, M. and M. Lim. (2009). "Towards a critical political marketing agenda?" Journal of Marketing Management 25 (7-8): 763-776. doi:10.1362/026725709X471613.

Muniz, A. M. and T. C. O'Guinn. (2001). "Brand community." The Journal of Consumer Research, Vol. 27, No. 4, p412-432. doi:10.1086/319618.

Nadeem, M. M. (2007). "Emergence of customer-centric branding: from boardroom leadership to self-broadcasting." Journal of American Academy of Business, Vol. 12, No. 1, pp. 44.

Nandan, S. (2005). "An exploration of the brand identity-brand image linkage: A communications perspective." Journal of Brand Management, Vol. 12, No. 4, pp. 264-278. doi:10.1057/palgrave.bm.2540222.

Needham, C. (2005). "Brand Leaders: Clinton, Blair and the Limitations of the Permanent Campaign." Political Studies 53 (2): 343-361. doi 10.1111/j.14679248.2005.00532.x

Neff, J. (2009). "Why it's time to do away with the brand manager." Advertising Age 80 (34): $1-2$.

Niffenegger, P. B. (1989). "Strategies for success from the political marketers." Journal of Consumer Marketing 6 (1): 45. doi:10.1108/EUM0000000002539.

Norton, P. (1996). The Conservative Party. Hertfordshire: Prentice Hall/Harvester Wheatsheaf.

Norton, P. (2008), “The Future of Conservatism.” Political Quarterly, Vol. 79, pp. $324-$ 332. doi:10.1111/j.1467-923X.2008.00935.X 
O'Shaughnessy, N. and S. Henneberg. (2007). "Theory and Concept Development in Political Marketing." Journal of Political Marketing 6 (2): 5-31. doi:10.1300/J199v06n02_02

Osuagwu, L. (2008). "Political Marketing: conceptualisation, dimensions and research agenda." Marketing Intelligence \& Planning 26 (7): 793-810. doi:10.1108/02634500810916726.

Palazzo, G. and K. Basu. (2007). “The ethical backlash of corporate branding." Journal of Business Ethics 73 (4): 333-346. doi:101007/s1055-006-9210-6.

Panwar, J. S. (2004) Beyond Consumer Marketing: Sectional Marketing and Emerging Trends, London: Sage.

Papasolomou, O. and D. Vrontis. (2006a). "Building corporate branding through internal marketing: the case of the UK retail bank industry." Journal of Product \& Brand Management 15 (1): 37 - 47. doi:10.1108/10610420610650864.

Papasolomou, O. and D. Vrontis. (2006b). "Using internal marketing to ignite the corporate brand: the case of the UK retail bank industry." Journal of Brand Management, 14 (1/2): 177-195. doi:10.1057/palgrave.bm.2550059.

Parry, G., G. Moyser and N. Day. (1992), Political participation and democracy in Britain, Cambridge: Cambridge University Press.

Peng, N. and C. Hackley. (2009) "Are Voters, Consumers? A qualitative exploration of the voter-consumer analogy in political marketing." Qualitative Market Research: An International Journal 12 (2): 171-186. doi: 10.1108/13522750910948770.

Phipps, M., J. Brace-Govan and C. Jevons, C. (2010). "The Duality of Political Brand Equity." European Journal of Marketing 44 (3/4): 496-514. doi:10.1108/03090561011020552.

Piercy, N. F. (1995). "Customer satisfaction and the internal market - marketing our customers to our employees." Journal of Marketing Practice: Applied Marketing Science 1 (1): 22-44. doi:10.1108/EUM0000000003878.

Punjaisri, K., A. Wilson and H. Evanschitzky. (2009). "Internal branding to influences employees' brand promise delivery: A case study in Thailand." Journal of Service Management 20 (5): 57-70. doi:10.1108/09564230910995143.

Punjaisri, K. and A. Wilson. (2007), "The role of internal branding in the delivery of employee brand promise." Journal of Brand Management 15 57-70. doi:10.1057/palgrave.bm.2550110.

Rafiq, M. and P. K. Ahmed. (1993). "The scope of internal marketing: defining the boundary between marketing and human resource management." Journal of Marketing Management 9 (3): 219-232. doi:10.1080/0267257X.1993.9964234.

Rawson, E. A. G. (2007). "Perceptions of the United States of America: Exploring the political brand of a nation." Place Branding and Public Diplomacy 3 213-221. doi:10.1057/palgrave.pb.6000067.

Reeves, P., L. de Chernatony and M. Carrigan. (2006). "Building a political brand: Ideology or voter-driven strategy. " Journal of Brand Management, 13 (6): 418428. doi:10.1057/palgrave.bm.2540283.

Robinson, J. (2004). "Repackaging our Politicians: Marketing MPs in an MMP world." NZ Marketing Magazine 23 (5):12-19.

Roper, S. and C. Parker. (2006). "Evolution of Branding Theory and its Relevance to the Independent Retail Sector.” The Marketing Review 6 (1): 55-71. doi:10.1362/146934706776861555

Rubin, H. J. and I. S. Rubin. (1995). Qualitative Interviewing: The Art of Hearing Data, London: Sage.

Scammell, M. (1995). Designer Politics: How Elections are Won, London: Macmillan. 
Schneider, G. (2008). "Obama shows the way - and the value - of building brand.” PRWeek 911.

Smith, G. (2001). "The 2001 General Election: Factors influencing the brand image of political parties and their leaders." Journal of Marketing Management 17 (9/10) 1058-73. doi: 10.1362/026725701323366719.

Smith, G. (2009). "Conceptualising and testing brand personality in British politics." Journal of Political Marketing 8 (3): 209-232. doi: 10.1080/15377850903044858.

Smith, G. and A. French. (2009). "The political brand: A consumer perspective." Marketing Theory 9 (2): 209-226. 10.1177/1470593109103068.

Sonnenberg, F. K. (1991). “Internal communication: turning talk into action.” Journal of Business Strategy 12 (6): 52-55. doi:10.1108/eb039457.

Switzer, T. (2009). "New world leaders and the politics of power." Review - Institute of Public Affairs 61 (1): 15-17.

Tan, T. and M. Ming. (2003). "Leveraging on symbolic values and meanings in branding." Journal of Brand Management 10 (3): 208-218. doi:10.1057/palgrave.bm.2540117.

Terry, N. (2003). "Marketers merit a greater role in internal activity." Marketing, August $28^{\text {th }}$, 18.

Urde, M. (2009). "Uncovering the corporate brand's core values". Management Decision 47 (4): 616-638. doi:10.1108/00251740910959459.

Vallaster, C. and L. de Chernatony. (2006). "Internal brand building and structuration: the role of leadership." European Journal of Marketing 40, (7/8): 761-784. doi:10.1108/03090560610669982.

Van Ham, P. (2001). "The rise of the brand state: the postmodern politics of image and reputation." Foreign Affairs 80 (5): 2-6.

Van Riel, C. and C. J. Fombrun, (2007). Essentials of Corporate Communication. Oxon: Routledge.

Varey, R. J. (1995), "Internal marketing: a review and some interdisciplinary research challenges." International Journal of Service Industry Management 6 (1): 40-63. doi: $10.1108 / 09564239510078849$

Vargo, S. L. and R. F. Lusch. (2004), 'Evolving to a new dominant logic for marketing", Journal of Marketing 68 (1): 1-17.

Veloutsou, C. (2008). "Branding: A constantly developing concept", Journal of Brand Management 15 (5): 299-300. doi:10.1057/bm.2008.2.

Wangenheim, F. H. Evanschitzky and M. Wunderlich (2007). "The employee-customer satisfaction link: does it hold for all employee groups?" Journal of Business Research 60 (7): 690 - 697. Doi:10.1016/j.jbusres.2007.02.019

Warren, C. A. B. and T. X. Karner. (2005). Discovering qualitative methods: Field research, Interviews and Analysis. California: Roxbury.

Webb, P. D. (1994). "Party organisational change in Britain: The iron law of centralisation', In How Parties organise. Change and Adaptation in Party Organisations in Western Democracies edited by R. S. Katz and P. Mair. London: Sage.

Willetts, D. and R. Forsdyke, R. (1999), After the Landslide: Learning the Lessons from 1906 and 1945. London: CPS

Wheatcroft, G. (2005). The Strange Death of Tory England. London: Penguin

White, J. and L. de Chernatony. (2002). "New Labour: A study of the creation, development and demise of a political brand". Journal of Political Marketing, 1 (2/3): 45-52. 
Whiteley, P. F. P. Seyd, J. Richardson and P. Bissell. (1994). "Explaining party activism: The Case of the British Conservative Party." British Journal of Political Science 24 (1): 79-94.

Wood, L. M. (1999). "Market power and its measurement." European Journal of Marketing 33 (5/6): 612-631. doi10.1108/03090569910262224.

Woods, M. (2002). "Was there a rural rebellion? Labour and the countryside vote in the 2001 General Election'. In British Elections and Party Review, Vol. 12 edited by L. Bennie, C. Rallings, J. Tonge and P. Webb. London: Frank Cass

Worcester, R. M. and P. Baines. (2006).’'Voter research and market positioning. triangulation and its implications for policy development." In Winning Elections with Political Marketing, edited by P. Davies and B. Newman. New York: Howarth Press.

Wring, D. (2005). The Politics of Marketing the Labour Party. Hampshire: Palgrave Macmillan.

Zucker, R. (2002). "More than a name change: Internal branding at Pearl”. Strategic Communication Management 6 (4): 4-7. 


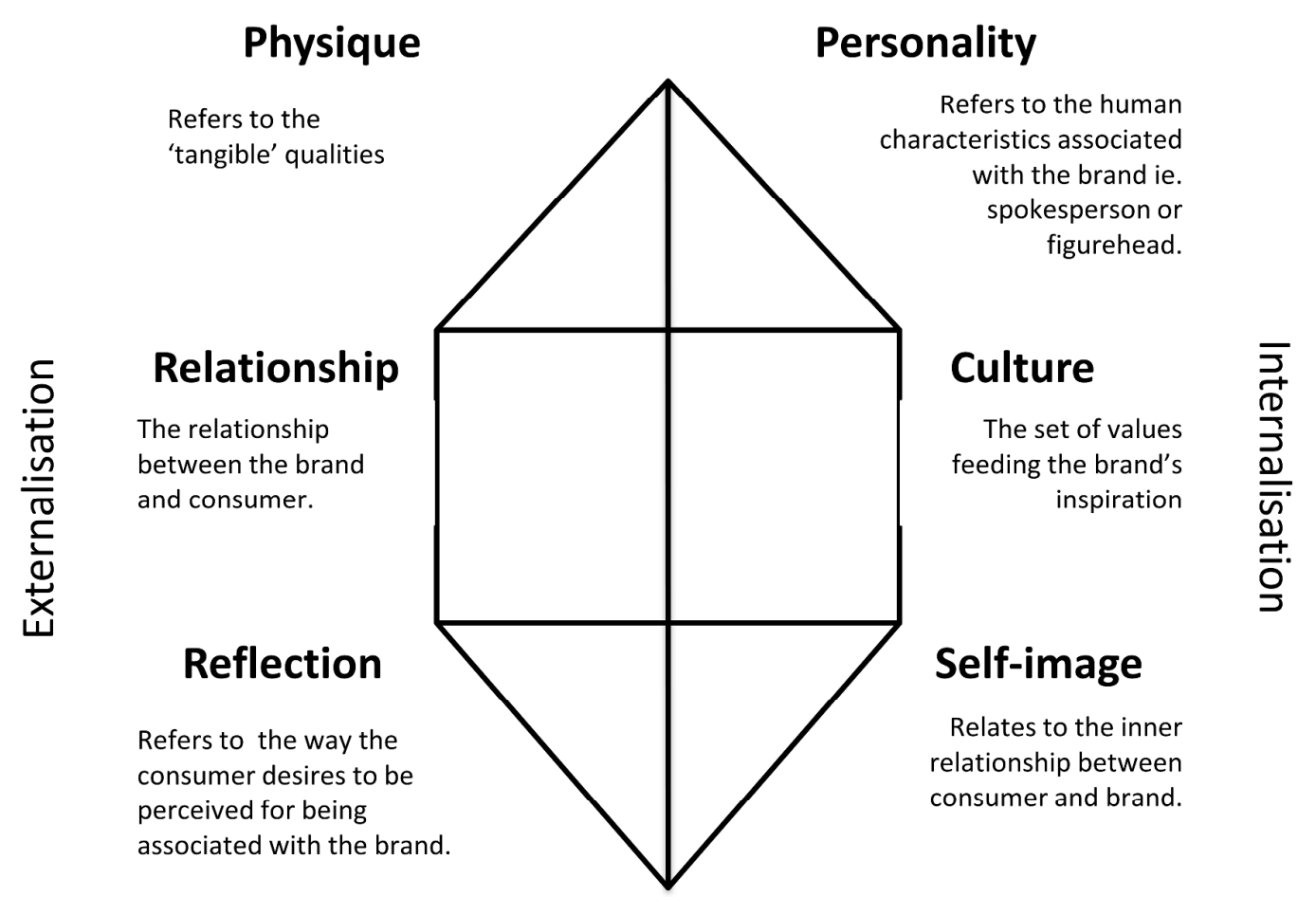

Figure 1: Kapferer's Brand Identity Prism

(Adapted from de Chernatony 2006; Fill 2006:397; Kapferer 2008) 


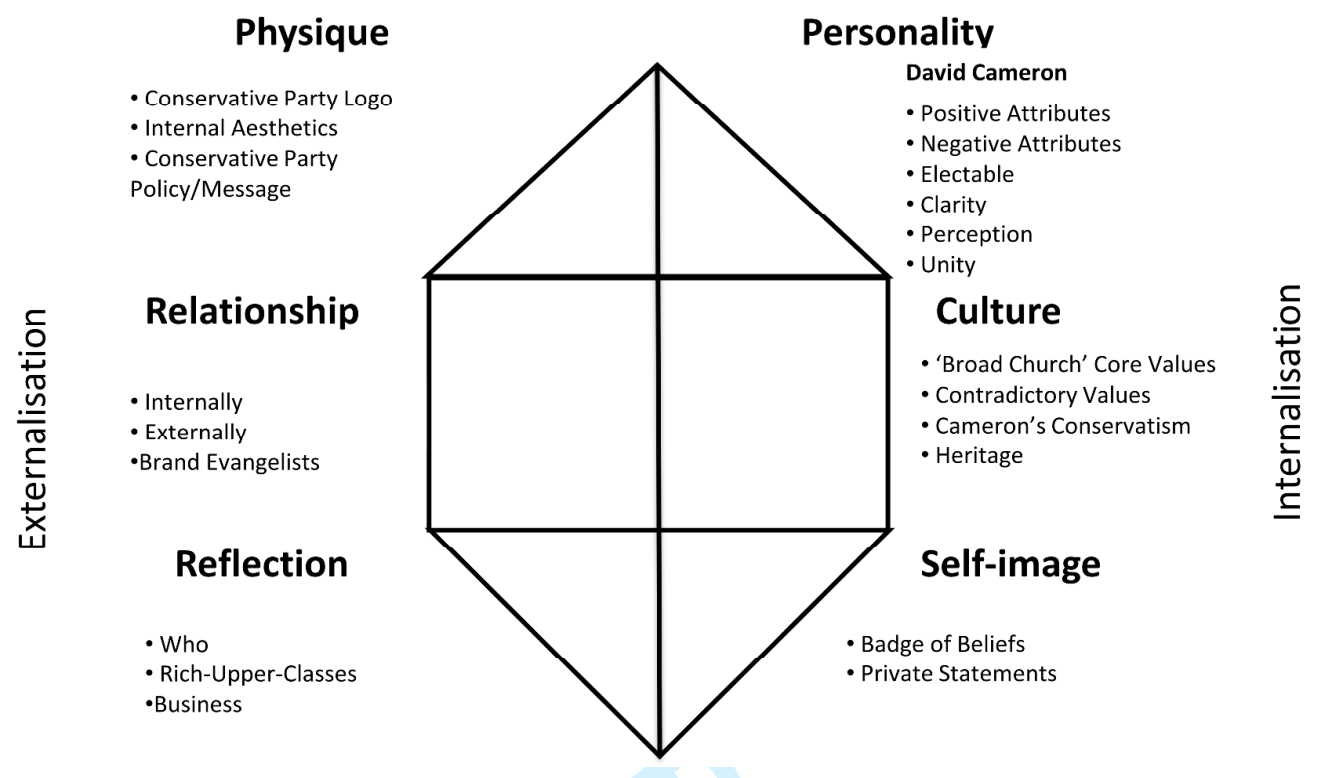

Figure 2: UK Conservative Party Brand and the Brand Identity Prism 
Dear Sir/Madam

I would like to thank the reviewers for their constructive and helpful comments and in this revision we have taken these into consideration. We have made modifications to the paper in three sections, the literature review on brand identity, the methodology section and finally the implications section.

In response to the comments "although some brief discussion of the merits strengths/weaknesses/limitations of the concept would provide a little more critical depth", we have redrafted the brand identity section of the paper providing a deeper critical discussion of the brand identity literature also adopted a critical analysis of Kapferer's brand prism. Thirdly we have developed a stronger justification for the application of the model to analyse the UK Conservative Party.

We have responded to the comments on the methodological approach by extending the methodology section to include an explanation of the data collection method and also how the data was organised into themes and then analysed.

The implications section has been significantly amended to take into consideration the reviewers comments on providing a discussion on the implications for the internal market and political branding. The key points we make are related to core and peripheral values; the need for greater flexibility with peripheral values at a local level and harnessing the enthusiasm of the brand evangelists. We have emphasised why this research is important and how, when branding theory is applied to political branding there are human dynamics that also need to be incorporated into the brand identity. This is related to the party leadership but also to the party members and activists.

Finally, we have added a graphic representation of Kapferer's brand prism and the Conservative party.

I hope these have been completed to the satisfaction of the reviewers and once again thank them for their advice. 